\title{
The North American automotive value chain: Canada's role and prospects
}

\section{Timothy J. Sturgeon*}

Massachusetts Institute of Technology,

Cambridge, MA, USA

E-mail: sturgeon@mit.edu

*Corresponding author

\section{Johannes Van Biesebroeck}

University of Toronto,

Ontario, Canada

E-mail: jovb@chass.utoronto.ca

\section{Gary Gereffi}

Duke University,

Durham, NC, USA

E-mail: ggere@soc.duke.edu

\begin{abstract}
This paper deals with the North American automotive value chain and analyses the prospects for Canadian automotive sector upgrading. The size and importance of the automotive industry in Canada's Ontario Province is a legacy of its historic ties to the 'Big 3' US automakers and its proximity to the traditional heartland of the US industry in Michigan. Canada continues to have marginally lower operating costs than the USA and a strong industrial culture that attracts investment. But Mexico's integration into the North American production system, the rise of new centres of automotive production in the southern USA and rapidly growing flow of automotive parts from China to North America have begun to erode this advantage. Because the North American market is saturated, consisting mainly of sales of replacement vehicles, locational shifts in production and employment within North America are essentially 'zero-sum games'. If the market share of the Big 3 continues to fall and the southward shift of the industry within the USA is maintained, the sustainability of the Canadian industry could be undermined. The paper concludes with a set of policy recommendations for Canada to maintain its comparative advantage in the industry.
\end{abstract}

Keywords: North America; automotive value chain; Canada; industrial upgrading.

Reference to this paper should be made as follows: Sturgeon, T.J., Van Biesebroeck, J. and Gereffi, G. (2009) 'The North American automotive value chain: Canada's role and prospects', Int. J. Technological Learning, Innovation and Development, Vol. 2, Nos. 1/2, pp.25-52.

Biographical notes:Timothy J. Sturgeon is a Senior Research Affiliate at the Industrial Performance Center (IPC) at the Massachusetts Institute of Technology (MIT). He served as Executive Director of the IPC's Globalization 
Study, and Globalization Research Director for the International Motor Vehicle Program at the Center for Technology, Policy and Industrial Development. He has a PhD in Economic Geography from U.C. Berkeley, and is Co-Organiser of the Global Value Chains Initiative (www.globalvaluechains.org). His papers have appeared in international peer-reviewed journals including Industrial and Corporate Change, Review of International Political Economy, Journal of East Asian Studies and Journal of Economic Geography, and as chapters in edited volumes, the most recent being, 'From commodity chains to value chains, interdisciplinary theory building in an age of globalization', in Jennifer Bair (Ed.) Frontiers of Commodity Chain Research, Stanford University Press, forthcoming, October 2008.

Johannes Van Biesebroeck is an Associate Professor of Economics at the University of Toronto and a Faculty Research Fellow at the National Bureau of Economic Research. He has served as a Consultant on the automotive industry for Industry Canada and International Trade Canada, most recently investigating the potential impact of the Free Trade Agreement with South Korea. His work on the automobile industry has been supported with grants by the Social Science and Humanities Research Council, the Canadian Foundation for Innovation and the Ontario Innovation Trust, and for his current research on supply chains. He is a Network Researcher of AUTO21, the Canadian Network of Centers of Excellence and of the International Motor Vehicle Program in Boston. His papers on the automotive industry have appeared in international refereed journals like the Review of Economic Studies, the Journal of Applied Econometrics, Assembly Automation and the Economic and Social Review.

Gary Gereffi is Professor of Sociology and Director of the Center on Globalization, Governance and Competitiveness at Duke University (http://www.cggc.duke.edu/), where he teaches courses in economic sociology, globalisation and comparative development and international competitiveness. $\mathrm{He}$ received his BA degree from the University of Notre Dame and his $\mathrm{PhD}$ degree from Yale University. Gereffi has published six books and numerous articles on business-government relations in various parts of the world. His books include: Commodity Chains and Global Capitalism (Praeger Publishers, 1994); The Value of Value Chains: Spreading the Gains from Globalisation (special issue of the IDS Bulletin, Vol. 32, No. 3, July 2001) and Free Trade and Uneven Development: The North American Apparel Industry after NAFTA (Temple University Press, 2002).

This paper benefited from the research assistance provided by Anne Bax and Kimberly Rogers from Duke University. Comments on an earlier draft from Industry Canada were extremely helpful. Responsibility for the content, however, rests with the authors.

\section{Introduction}

This paper examines trends in the North American automotive industry and considers Canada's comparative advantage and its sustainability. The automotive industry is Canada's most important manufacturing and export sector. In 2005, it employed 7.7\% of the manufacturing workforce and accounted for nearly a third of manufactured goods exports while the 12 high-volume final assembly plants directly employed more than 51,000 workers. ${ }^{1}$ More than two and a half million vehicles were produced, valued at C\$69.8 billion, of which nearly $85 \%$ was exported. ${ }^{2}$ The automotive parts sector is an even larger employer. In 2005, 97,000 workers in 941 establishments produced 
C $\$ 32.2$ billion worth of original equipment and aftermarket auto parts, components and sub-systems. Although Canada's C $\$ 22.2$ billion trade surplus in finished vehicles was diminished by a $\mathrm{C} \$ 17.7$ billion deficit in parts, local value-added stood at a robust C $\$ 33.3$ billion in $2003 .^{3}$ The industry is heavily concentrated within the province of Ontario.

The size and importance of the automotive industry in Canada's Ontario Province is a legacy of its historic ties to the 'Big 3' US automakers - General Motors (GM), Ford and Chrysler, and Ontario's proximity to the traditional heartland of the US industry in Michigan and the surrounding mid-western states. Canada had, and continues to have, marginally lower operating costs than the USA and a strong industrial culture that attracts investment. But Mexico's integration into the North American production system and the rise of the southern USA as a new centre of automotive production have begun to erode this advantage. Because the North American market is saturated, consisting mainly of sales of replacement vehicles, locational shifts in production and employment within North America are essentially 'zero-sum games', with some places losing out as others gain. If the market share of the Big 3 continues to fall and the southward shift of the industry within the USA is maintained - both very likely scenarios - this could threaten the sustainability of the Canadian industry over the long term. ${ }^{4}$ This uncertainty, coupled with the industry's importance to Canada, has attracted the attention of policymakers to ensure that the nation continues to provide employment in manufacturing and sustains its trade surplus.

This paper is organised in four parts. Section 2 examines the regional production system in North America and its shift to the south of the USA and Mexico as a production platform for parts and final assembly for the region. Section 3 presents evidence on the growing importance of large suppliers and illustrates how this trend relates to the changing geography of the automotive industry. Section 4 examines the role of Canadian firms in the North American automotive industry. Three trends that pose a challenge to the Canadian automotive industry are highlighted:

- the gradual shift of North American production to the south of the USA and Mexico

- the shift of value-added and employment from assemblers to parts suppliers

- the small, but rapidly growing, flow of automotive parts from China to North America.

Section 5 identifies priority areas for policymakers seeking to maintain the historic strength of the Canadian automotive sector.

\section{The North American automotive production system}

Of the three major vehicle-producing regions, North America, Europe and East Asia, regional integration is the most pronounced in North America. In 2004, 75.1\% of automotive industry trade was intra-regional, in contrast to $71.2 \%$ in Western Europe, $23 \%$ in Asia and $13.2 \%$ in Latin America (Dicken, 2006, p.305). North America's share of world vehicle production has fallen steadily from $33 \%$ in 1975 to $25 \%$ in 2005 (Figure 1) because of market growth outside North America and the tendency to produce in or near end markets. The North American industry is focused on supplying the USA, which is the world's largest single national market. The integration of Canada into the North American production system began in 1965 with the US-Canada Auto Pact, which 
reduced tariffs on many vehicles entering the USA. Mexico's integration came with the North American Free Trade Agreement (NAFTA) in 1994. As a result of these agreements and their implementation, vehicle production in Canada and Mexico increased. In 2005, 95.2\% of Canada and Mexico's combined vehicles and parts exports were destined for the US market (UN Comtrade).

Figure 1 North America's falling relative importance in global vehicle production (see online version for colours)

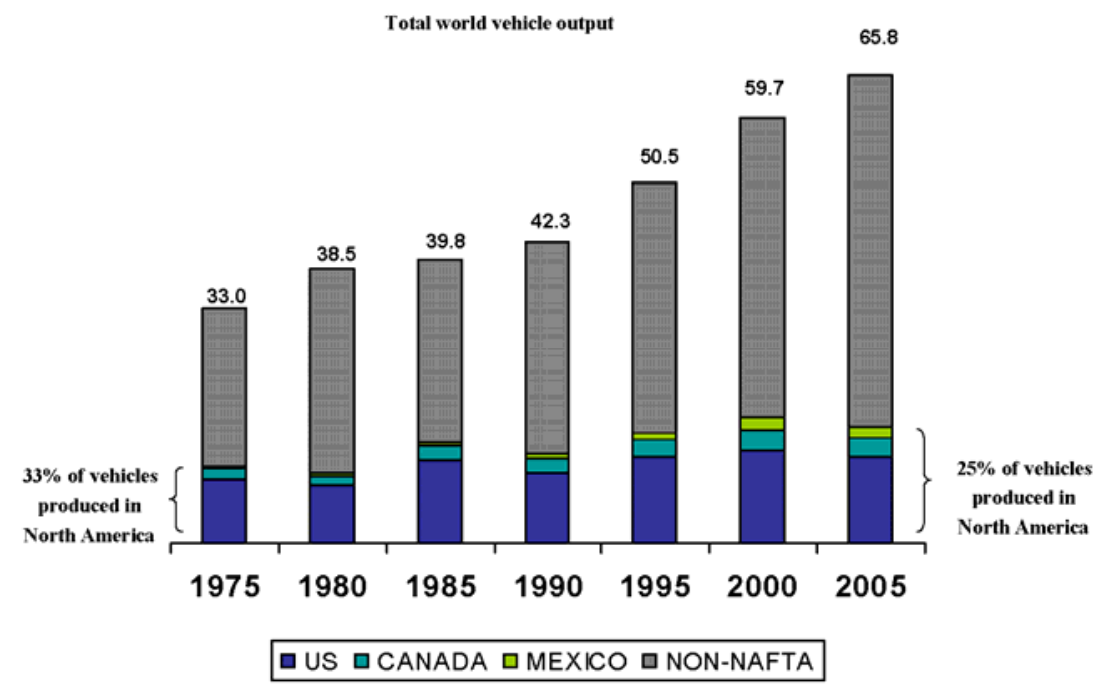

Note: Includes cars and trucks.

Source: Automotive News Market Data Books

As Canada and Mexico have become more tightly integrated into the North American production system, vehicle assembly in the region has become concentrated in fewer, larger plants. In 1985, there were 93 plants manufacturing cars and light trucks in North America: 4 in Mexico, 14 in Canada and 75 in the USA. By 2005, the total number of assembly plants in North America shrank to 83, with nearly all of the closures coming in the USA, while the number of plants in Mexico increased to 12. During the same period, the share of North American final assembly plants owned by Asian automakers increased from $2 \%$ to $21 \%{ }^{5}$

According to Ward's Automotive Yearbook, combined car and light truck sales in the USA totalled 17.4 million units in $2005 .^{6}$ As shown in Table 1, the share of apparent US demand (the number of vehicles produced in the USA, plus net imports) met by regional production increased steadily, from $80.3 \%$ to $92.7 \%$ between 1989 and 1996. After 1996, the share began to fall, reaching $81.2 \%$ in 2002 and increasing slightly to $82 \%$ in 2005 . Most of this change was accounted for by reductions in US production by the Big 3 , and a rise in imports from outside the region, mostly from Japan and the Republic of Korea as firms such as Toyota, Honda and Hyundai increased their share of the US market. Mexico and Canada's combined share of total apparent US demand continued to rise until 2000, when it reached a peak of $14.4 \%$; by 2005 it had fallen to $12.1 \%$. Vehicle imports from outside NAFTA, after dropping from around $20 \%$ in 1989 to a low of $7 \%$ in 1996 , surged back to around $18 \%$ in $2004-2005$, largely at the expense of US production. 
The same trade data, shown in graphic form in Figure 2, illustrate the dramatic decline in vehicle imports from countries outside NAFTA in the period 1989-1996, and the equally dramatic increase thereafter. This reflects the establishment of enough production capacity in North America during the 1980s and early 1990s to supply about two-thirds of demand for Japanese-brand vehicles, and the limits of this 'transplant' capacity as Japanese market share in North America has continued to grow after 1996. Imports from Canada and Mexico increased through the 1989-2000 period, and have fallen slightly since, reflecting the declining market share of the Big 3, whose plants dominate production in these countries.

Table 1 Share of apparent US demand met by US production, NAFTA imports and imports from the rest of the world, 1989-2005 (see online version for colours)

\begin{tabular}{|ccccc|}
\hline Year & US production (\%) & $\begin{array}{c}\text { Net NAFTA } \\
\text { imports (\%) }\end{array}$ & $\begin{array}{c}\text { Net ROW } \\
\text { imports (\%) }\end{array}$ & $\begin{array}{c}\text { US plus } \\
\text { NAFTA (\%) }\end{array}$ \\
\hline 1989 & 73.1 & 7.2 & 19.7 & 80.3 \\
1990 & 72.2 & 9.2 & 18.6 & 81.4 \\
1991 & 72.4 & 9.8 & 17.7 & 82.3 \\
1992 & 76.0 & 11.0 & 13.0 & 87.0 \\
1993 & 77.1 & 11.9 & 11.0 & 89.0 \\
1994 & 78.9 & 10.8 & 10.3 & 89.7 \\
1995 & 78.7 & 12.9 & 8.4 & 91.6 \\
1996 & 78.9 & 13.8 & 7.3 & 92.7 \\
1997 & 78.4 & 12.5 & 9.1 & 90.9 \\
1998 & 76.5 & 12.7 & 10.7 & 89.3 \\
1999 & 72.7 & 13.8 & 13.5 & 86.5 \\
2000 & 69.8 & 14.4 & 15.8 & 84.2 \\
2001 & 68.4 & 13.9 & 17.7 & 82.3 \\
2002 & 68.9 & 12.3 & 18.8 & 81.2 \\
2003 & 69.8 & 12.0 & 18.2 & 81.8 \\
2004 & 68.8 & 12.6 & 18.5 & 81.5 \\
2005 & 69.9 & 12.1 & 18.0 & 82.0 \\
\hline & & & 79.5 & \\
\hline
\end{tabular}

Sources: US Production: Ward's Automotive Yearbook; Trade: UN Comtrade

However, it is likely that a number of new North American assembly plants planned by Japanese and Korean firms will largely offset this recent increase in imports from countries outside NAFTA. A new Hyundai plant with the capacity to produce 300,000 vehicles per year opened in Hope Hull, Alabama, in May 2005. Toyota will open a new plant in Woodstock, Ontario, in 2008 to produce up to 150,000 RAV4 Sport Utility Vehicles (SUVs) per year. Honda is slated to open a new assembly plant in Indiana in late 2008 with an annual capacity of 200,000 vehicles. Kia has announced the construction of a new assembly plant scheduled to open in Troup County, Georgia, in 2009 with a capacity to produce 300,000 vehicles per year. 
Figure 2 US car and light truck sales with net vehicle imports to the USA from Mexico, Canada and countries outside North America, 1989-2005

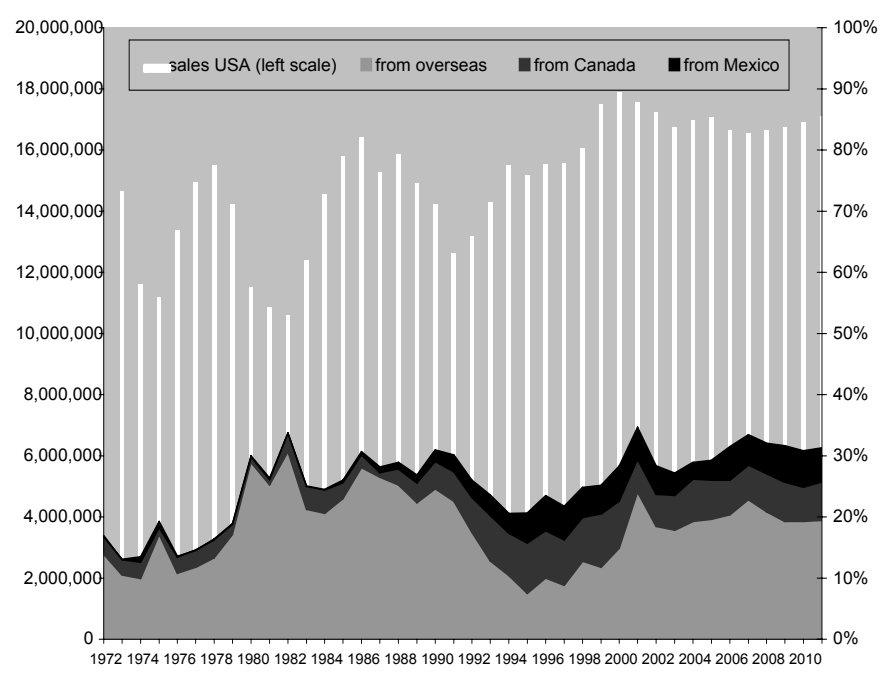

If all of these plants are built, and the average production capacity of the new plants is a conservative 200,000 vehicles per year, the recent increases in imports to North America will be replaced by regional production. Because of the high cost and large scale of vehicle assembly plants, this sort of cyclical variation in the share of regional production can be expected in the future if market share continues to shift in favour of foreign firms. Assembly plants will only be added when these firms are confident that market share gains in North America will be longstanding. In particular, firms want to ensure that their plants in locations with the highest operating costs, usually those in the home base, will continue to work as close to full capacity as possible, and are therefore conservative about making new investments given the large scale and long life of the vehicle assembly plants.

\subsection{A shift to the south?}

Automotive manufacturing activity in North America is gradually shifting from its heartland in the American Midwest and Ontario to the southern USA and, to a lesser degree, Mexico. As Table 2 shows, 9 of the 12 new assembly plants already established or scheduled to open between 1990 and 2009 are or will be located in the American South or in Mexico. Political considerations have halted the shift to the south so that it remains north of the Mexican border. The USA has received the lion's share of new investment, as Asian automakers have increased production in the region. Planned investments are also concentrated in the USA.

Growth of the industry in Mexico has been stymied by the poor performance of the American Big 3 automakers, as well as fear of a political backlash from entrenched management, labour unions, and the general public. Mexico's vehicle production rose rapidly between 1985 and 1990, almost doubling from 433,212 to 801,137 units, but it took 15 years to double again, reaching 1.86 million units in 2005. While Mexico's share of North America's vehicle output grew from $3.2 \%$ in 1985 to $10.9 \%$ in 2000 , it has 
declined modestly to $10.3 \%$ since (Ward's Automotive Yearbook). More importantly, given their rising share of vehicle sales in North America, the share of Mexico's production accounted for by Asian automakers increased very modestly, from $22.0 \%$ in 1985 to $25.4 \%$ in 2005 .

Table 2 Light vehicle production by country and automaker home region, 2005 and 2010 projection (see online version for colours)

\begin{tabular}{|c|c|c|c|c|c|c|}
\hline & \multicolumn{3}{|c|}{2005} & \multicolumn{3}{|c|}{2010} \\
\hline & Mexico & Canada & USA & Mexico & Canada & $U S A$ \\
\hline \multicolumn{7}{|l|}{ Number of vehicles: } \\
\hline Big 3 & 895,532 & $1,741,426$ & $7,666,095$ & $1,329,000$ & $1,412,000$ & $6,966,000$ \\
\hline Asian & 396,387 & 691,457 & $2,947,778$ & 473,000 & $1,030,000$ & $4,146,000$ \\
\hline $\mathrm{JV}$ & 0 & 189,997 & 690,001 & 0 & 200,000 & 190,000 \\
\hline European & 313,929 & 0 & 220,376 & 330,000 & 0 & 243,000 \\
\hline Total & $1,605,848$ & $2,622,880$ & $11,524,250$ & $2,132,000$ & $2,642,000$ & $11,545,000$ \\
\hline $\begin{array}{l}\text { (North American } \\
\text { share) }\end{array}$ & $(10.2 \%)$ & $(16.7 \%)$ & $(73.2 \%)$ & $(13.1 \%)$ & $(16.2 \%)$ & $(70.7 \%)$ \\
\hline \multicolumn{7}{|c|}{ Market share by country: } \\
\hline Big 3 & $55.8 \%$ & $66.4 \%$ & $66.5 \%$ & $62.3 \%$ & $53.4 \%$ & $60.3 \%$ \\
\hline Asian & $24.7 \%$ & $26.4 \%$ & $25.6 \%$ & $22.2 \%$ & $39.0 \%$ & $35.9 \%$ \\
\hline JV & $0.0 \%$ & $7.2 \%$ & $6.0 \%$ & $0.0 \%$ & $7.6 \%$ & $1.6 \%$ \\
\hline European & $19.5 \%$ & $0.0 \%$ & $1.9 \%$ & $15.5 \%$ & $0.0 \%$ & $2.1 \%$ \\
\hline Total & $100.0 \%$ & $100.0 \%$ & $100.0 \%$ & $100.0 \%$ & $100.0 \%$ & $100.0 \%$ \\
\hline
\end{tabular}

Note: In 2010, the NUMMI plant in Fremont is no longer split out from the rest of Toyota and is included with 'Asian', while in 2005 it was under JV.

Source: Industry Canada, and CSM forecasting 2006

As shown in Table 2, the Asian automakers' share of production is approximately $25 \%$ in all three North American countries. Even without taking additional Big 3 plant closures in Table 3 into account, the scheduled plant additions in Canada and the USA summarised in Table 4 will increase the Asian share of vehicle assembly to more than $35 \%$ by 2010 . Given the planned investments, the distribution of production between the three countries is likely to be stable between 2005 and 2010, with a slight increase in the USA relative to Mexico and Canada. (However, as discussed in the following section, parts production has increased dramatically in Mexico.) This move of vehicle assembly to the south, therefore, will largely occur within the USA. It is being driven by shifts in market share, away from the Big 3 automakers and towards Asian automakers.

According to the Automotive News Market Data Books, the Big 3 automakers' share of the North American passenger car market has fallen dramatically, from $94 \%$ to $48 \%$, over the period 1985-2005. US automakers increased their share of the North American market for vans and light trucks, from $13.8 \%$ to $60 \%$ over the period 1955-2005. But rising fuel prices and recent success by Asian automakers in the markets for full-size pick-up trucks and SUVs have begun to undermine even this advantage. According to J.D. Power, a market research company, the Big 3 automakers are expected to continue to lose their share of the total US passenger vehicle market (cars, vans and light trucks) to European and Asian automakers. Their market share stood at $71.7 \%$ in 1995 and at around $60 \%$ in 2005 . By 2011, J.D. Power expects this figure to fall to $51.8 \%$ (cited in McAlinden, 2006). 
Table 3 Recently announced Big 3 assembly plant employment cuts in North America (see online version for colours)

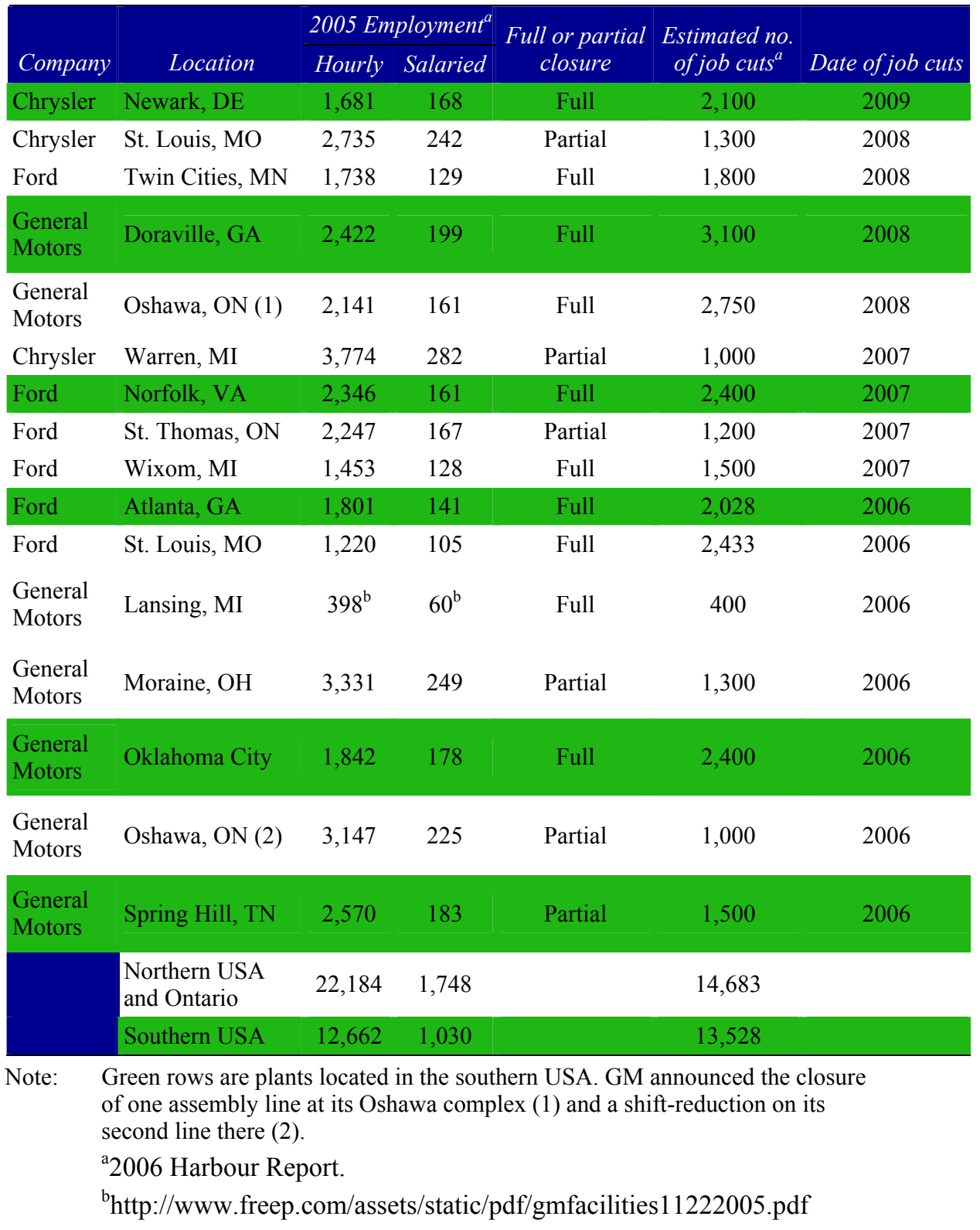

Declining market share has motivated the Big 3 to retool and expand older plants in Mexico to supply the local market, but has, at the same time, blocked large-scale expansion for export to the USA. Of the foreign assemblers, only Volkswagen and Nissan have made large-scale, export-oriented investments in Mexico by upgrading older, low-volume plants for export. Asian automakers, for the most part, have chosen to invest heavily in the Midwest and Ontario and most recently in the south of the USA. 
Table 4 Recent foreign assembly plant investment in North America (see online version for colours)

\begin{tabular}{|c|c|c|c|c|c|}
\hline Company & Location & $\begin{array}{l}\text { Employment } \\
\text { (as of } 2004 \\
\text { or planned) }\end{array}$ & $\begin{array}{l}\text { Investment } \\
\text { (US\$ million } \\
\text { through } 2005 \\
\text { or planned) }\end{array}$ & $\begin{array}{c}\text { Capacity (2005 } \\
\text { or planned) }\end{array}$ & $\begin{array}{c}\text { Opening date } \\
\text { (first major } \\
\text { expansion) }\end{array}$ \\
\hline Kia & Troup County, GA & 2,500 & 1,200 & 300,000 & 2009 \\
\hline Honda & Greensburg, IN & 2,000 & 550 & 200,000 & 2008 \\
\hline Toyota & Woodstock, ON & 2,000 & 950 & 150,000 & 2008 \\
\hline Toyota & San Antonio, TX & 2,000 & 850 & 200,000 & 2006 \\
\hline Hyundai & Hope Hull, AL & 2,000 & 1,100 & 300,000 & 2005 \\
\hline Toyota & Tecate, MX & 460 & 140 & 50,000 & 2005 \\
\hline Nissan & Canton, MS & 4,100 & 1,430 & 400,000 & 2003 \\
\hline Honda & Lincoln, AL & 4,300 & 1,200 & 300,000 & 2001 \\
\hline Volkswagen & Puebla, MX & 15,000 & & 380,000 & $1966(1998)$ \\
\hline Daimler-Benz & Vance, AL & 4,000 & 2,200 & 160,000 & 1997 \\
\hline Toyota & Princeton, IN & 4,659 & 2,600 & 300,000 & 1996 \\
\hline BMW & Spartenburg, SC & 4,600 & 2,200 & 200,000 & 1994 \\
\hline GM & Spring Hill, TN & 5,500 & & 300,000 & 1990 \\
\hline GM/Suzuki & Ingersoll, ON & 2,775 & 500 & 250,000 & 1989 \\
\hline Honda & East Liberty, OH & 2,230 & 920 & 240,000 & 1989 \\
\hline Subaru & Lafayette, IN & 1,315 & 1,350 & 262,000 & 1989 \\
\hline Toyota & Georgetown, KY & 6,934 & 5,310 & 500,000 & 1988 \\
\hline Mitsubishi & Normal, IL & 1,900 & 850 & 240,000 & 1988 \\
\hline Toyota & Cambridge, ON & 4,342 & 2,400 & 250,000 & 1988 \\
\hline Honda & Alliston, ON & 4,375 & 1,500 & 250,000 & 1987 \\
\hline GM/Toyota & Fremont, CA & 5,715 & 1,300 & 370,000 & 1984 \\
\hline Nissan & Smyrna, TN & 6,700 & 1,600 & 550,000 & 1983 \\
\hline Honda & Marysville, $\mathrm{OH}$ & 4,315 & 3,200 & 440,000 & 1982 \\
\hline \multirow[t]{3}{*}{ Nissan } & Aguascalientes, Mx & & & 200,000 & $1966(1982)$ \\
\hline & $\begin{array}{l}\text { Northern USA and } \\
\text { Ontario }\end{array}$ & 35,626 & 16,120 & $3,152,000$ & \\
\hline & $\begin{array}{l}\text { Southern USA and } \\
\text { Mexico }\end{array}$ & $58,094^{\mathrm{a}}$ & $17,230^{b}$ & $3,640,000$ & \\
\hline
\end{tabular}

Note: Green rows are located in the southern USA and Mexico. Dates in brackets indicate a major expansion of the plant.

${ }^{a}$ Missing employment from Nissan, Aguascalientes.

${ }^{\mathrm{b}}$ Missing investment in Volkswagen, Puebla, Nissan, Aguascalientes, and GM, Spring Hill plants.

Sources: Compiled from Automotive News, Ward's Automotive, McAlinden (2006), and company websites 
In response to reduced demand for large passenger vehicles and falling market share, the Big 3 automakers are cutting production in the USA. As Table 3 shows, the Big 3, in an effort to bring capacity in line with demand, have announced plans to cut more than 28,000 assembly jobs between 2006 and 2009 and similar announcements are being made regularly. So far, job cuts from these full and partial plant closures are distributed evenly across the northern (including Ontario) and southern USA.

Nevertheless, the fundamental geographic patterns in the North American automotive industry will not change quickly. The sunk capital, accumulated labour force skills and especially the broad and deep supply bases that exist in the American Midwest and Ontario make rapid or complete locational shifts highly unlikely, especially given the widespread adoption of just-in-time delivery and closer design collaboration between automakers and suppliers. Not only are such assets highly immobile, but also they continue to be attractive to new investment. As a result, the Midwest's share of employment in the US transportation sector remained steady between 1990 and 2005 at about $40 \%$, while employment in the south increased from $10 \%$ to just over $17 \%$ (McAlinden, 2006). Most of this increase has come at the expense of the northeastern and western regions of the USA, where the Big 3 had expanded production in the 1950s, 1960s and 1970s.

The earliest Japanese plants established in North America were located on the outer boundaries of the traditional cluster, in Ohio and Ontario. ${ }^{7}$ These plants have developed a dense network of surrounding suppliers. Toyota's huge production complex in Georgetown, Kentucky, which is labelled as 'southern' plant, is within a day's drive of the industry's Midwest heartland. In addition, large-scale investment in new assembly capacity continues to be made in the American Midwest and Ontario by the most successful Asian automakers (Honda and Toyota), even as more Big 3 assembly plants close and investment by Asian automakers in the American South accelerates. This means that any notion that the automotive industry in North America is shifting to the south needs to be tempered with a countervailing notion that the industry's traditional heartland in the upper Midwest and lower portion of Canada's Ontario Province will continue to be important, perhaps with a stronger participation from Asian automakers and their suppliers.

\section{The growing importance of large suppliers}

Beginning in the mid-1980s and accelerating in the 1990s, the automotive industry underwent a dramatic wave of outsourcing. This trend was most pronounced among suppliers headquartered in the USA. Figure 3, which traces the history of parts and assembly employment in the USA from 1958 to 2002, clearly shows this structural shift. Until 1985, employment was equally divided between parts and assembly. After 1985, employment shifted into the supply base as automakers closed feeder lines making sub-assemblies such as cockpit assemblies, rolling chassis, seats, radios, etc., and began to purchase built-up modules and sub-assemblies from outside suppliers. This drove rapid growth among the largest automotive parts suppliers as well as consolidation, as firms engaged in mergers and acquisitions in order to gain the capability to make larger and more complex sub-systems and modules. 
Figure 3 Outsourcing in the US automotive industry, assembly and parts employment, $1958-2002$

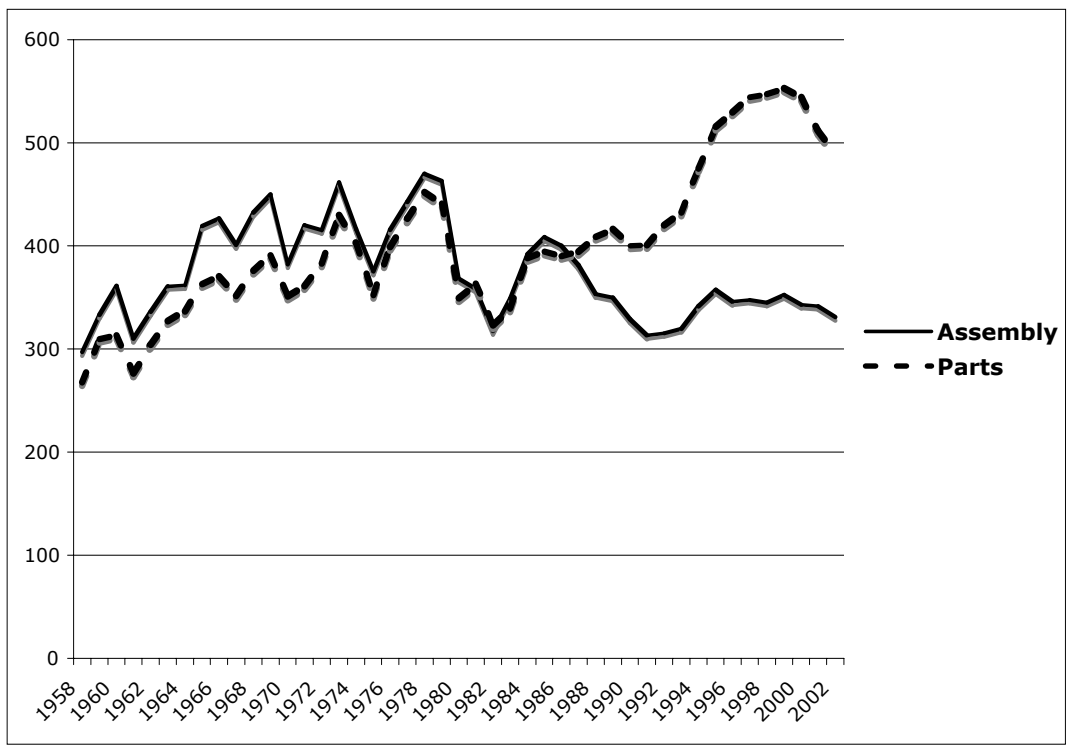

Note: $\quad$ Assembly includes SIC 3711 (motor vehicles and car bodies) and Parts includes SIC 3714 (motor vehicle parts and accessories). Employment, on the vertical axis, is in thousands of workers.

Source: Employment, Hours, and Earnings from the Current Employment Statistics Survey, US Bureau of Labour Statistics (National, SIC basis)

As large suppliers have captured an increasing share of employment in the sector, they have also gained control over their own upstream suppliers. Over time, the industry has organised itself into several tiers. First-tier suppliers sell directly to automakers, which assemble the final product. Second-tier suppliers sell to the first tier, etc., up the chain. As lead firms have delegated design tasks to their suppliers and started to source entire modules instead of individual parts, first-tier suppliers have gained considerable control over the value chain. ${ }^{8}$

Automotive News publishes a comprehensive overview of the largest automotive suppliers. Each year, a list is compiled of the top 150 parts suppliers in North America, the top 30 in Europe and the 100 largest suppliers worldwide. The list for North America was first published in 1992 and with the exception of 1994 it has appeared each year since. ${ }^{9}$ The European and worldwide lists have been published since 1999. The first visible trend is the rising importance of suppliers, relative to lead firms. The only output measure for the firms on the list is total sales in current US dollars, but it is useful to keep in mind that the price per vehicle (controlling for quality) has remained almost flat over the last 15 years. ${ }^{10}$ While the total number of vehicles produced in North America grew by $40 \%$ between 1991 and 2005 (from 11.6 million to 16.3 million), the combined sales value of the largest 150 suppliers in North America almost tripled over the same time period from US\$ 65.5 billion to US\$ 204.4 billion. 
At the global level, vehicle production increased by $18.4 \%$ from 1999 to 2005, while supplier sales grew at more than twice that pace. Total sales of the 100 largest global suppliers increased from US\$ 343.3 billion in 1999 to US\$ 503.4 billion in 2005, a growth rate of almost $50 \%$. Consolidation of suppliers at the worldwide level has not progressed as far as in North America, but it has picked up speed in recent years with the formation of new global automotive firms and groups: DaimlerChrysler in 1999; NissanRenault in 1998; Hyundai-Kia in 1999; and GM's and Ford's purchase of several smaller companies. These large multinationals have pressured their suppliers to attain global reach.

\subsection{Trends in parts production: the rise of Mexico and China}

Although large suppliers have set up global operations, day-to-day production in the automotive industry remains to a large extent organised at a regional level. From the Automotive News Top Suppliers rankings mentioned earlier, the share of sales that a supplier makes in its home region, Europe, North America, or Asia can be calculated. On average, this proportion declined only from approximately $68 \%$ in 1999 to $62 \%$ in 2005 . Given that the three regions are about equally important in vehicle production, selling two-thirds of output in a market that accounts for only one-third of final demand, the home market, is surprising for an industry that is assumed to operate globally.

One factor contributing to a lower share of home market sales is the growing importance of European and Japanese firms in the top 100 worldwide suppliers. Almost half of all large firms hailed from North America as recently as 1999, but this had declined to just over a third by 2005. Historically, North American firms have been especially focused on their home market and European firms the least. In addition, the decline of regional sales was more pronounced in North America than in the other two regions, making North American firms the least dependent on regional sales by 2005 .

Mexico has become important export platform for automotive parts within North America. In 1990, Mexico ranked third as an exporter of automotive parts to the USA (sending US\$ 5.2 billion worth of goods), well behind Japan (US\$ 10.2 billion) and Canada (US\$ 8.4 billion). By 2005, it occupied top position, with exports to the USA reaching US\$ 18.5 billion (see Table 5). Production of auto parts, especially electronics and other labour-intensive parts, began in the border region of Mexico well before NAFTA, with investments and sourcing driven by US firms seeking to cut costs.

But after NAFTA, investments surged in the interior. Except for investments to support Nissan's presence in Aguascalientes, the only high-volume Japanese-owned assembly plant in Mexico, Japanese parts suppliers have announced few sizable investments in Mexico, such as Ahresty's US\$ 66 million foundry in Zacatecas and Bridgestone's US\$ 81 million lampblack plant in Tamaulipas. Because they are so tightly tied to assembly plant investments, most investments by Japanese auto parts companies have been concentrated in the USA and Canada. As automobile production in Asia is growing, the supplier industry is adjusting as well. A strong production base for parts in Asia is reducing North American export potential, as lead firms can now source local parts for their Asian assembly plants. In addition, despite the strength of regional production in North America, automotive parts imports from low-wage Asian countries, especially China, are growing rapidly. Automotive parts exports from China to the USA increased by an annual average of $24 \%$ a year from 1990 to 2005 . 
The effect of rising exports of parts from China can be illustrated indirectly, by contrasting the relative fortunes of suppliers in North America with different product specialisations. For each of the firms listed in the top 150 Original Equipment Manufacturers (OEM) ${ }^{11}$ suppliers in North America, spanning the 1992-2005 period, a dummy variable was created indicating large exposure to Chinese imports. This variable was given a value of one if the firm specialised in automotive components for which the Chinese import share into the USA in 2005 was more than $10 \%$ (while the average Chinese import share for parts into the USA was just under 5\%). This was the case for the following products: wheels, clocks, accumulators, radiators, windshield wipers, lighting/visual signalling, wiring harnesses, horns and braking systems. ${ }^{12}$

Table 5 Automotive parts exports to the USA (US\$ million), 1990-2005(see online version for colours)

\begin{tabular}{|l|r|r|r|r|r|}
\hline Exporter & 1990 & 1995 & 2000 & 2005 & \multicolumn{1}{|c|}{ CAGR (\%) } \\
\hline India & 14 & 62 & 130 & 338 & 24 \\
\hline China & 183 & 635 & 1,609 & 4,393 & 24 \\
\hline Mexico & 5,154 & 8,945 & 14,570 & 18,535 & 9 \\
\hline Other Latin America & 74 & 136 & 227 & 234 & 8 \\
\hline South Korea & 586 & 378 & 690 & 1,724 & 7 \\
\hline Other Asia & 1,191 & 1,785 & 2,477 & 3,220 & 7 \\
\hline Europe & 4,340 & 4,280 & 6,245 & 9,202 & 5 \\
\hline Brazil & 483 & 457 & 892 & 977 & 5 \\
\hline Canada & 8,413 & 7,930 & 13,046 & 16,303 & 5 \\
\hline Japan & 10,189 & 12,166 & 11,913 & 13,504 & 2 \\
\hline Other & 78 & 281 & 763 & 1,555 & 11 \\
\hline Total US imports & 30,705 & 37,055 & 52,561 & 69,984 & 6 \\
\hline
\end{tabular}

Note: $\quad$ Europe includes countries in East Europe and Scandinavia. Includes parts for aftermarket sales and repair. CAGR is compound annual growth rate.

Source: UN Comtrade, SITC revision 3 codes $66481,69915,7132,7621,77313$, $77831 / 1$ and $77834 / 5,7842,78431,78432,78433,78434,78435,78436$, $78439,82112,88571$

Using regression analysis, it was found that annual sales growth is lower for firms that specialise in these 'at risk' products in each of the years between 1990 and 2005. Initially, the effect is close to zero, but it become large in absolute value and statistically significant after 2000. In each year between 2000 and 2005, sales growth for firms with a product mix that gave them a large exposure to Chinese imports has been 10-15\% lower than the average growth for the top suppliers (see also Van Biesebroeck, 2005). This increase coincides with China's entry into the WTO.

As Table 6 shows, US imports of auto parts nearly doubled between 1995 and 2005, from just under US\$ 35 billion to US\$ 68.5 billion. During this period, Canada's share of US parts imports remained constant at about 24\% while China's share increased from $1 \%$ to $5 \%$ and Mexico's increased from $18.5 \%$ to $28.3 \%$. Most critically, the parts in which the share of China and Mexico increased the most dramatically, such as electronics, 
brakes and seats, were by and large the segments in which Canada's share fell the most dramatically. While this suggests that Canadian firms and plants are making a transition from labour-intensive products (e.g. seats) to more technology and capital-intensive products (e.g. gearboxes and engine parts), these data provide little information from a global value chain perspective.

Table 6 China, Canada, and Mexico's share of US imports in 1995 and 2005, by part, ranked by China's share in 2005 (see online version for colours)

\begin{tabular}{|c|c|c|c|c|c|c|c|c|}
\hline \multirow[b]{3}{*}{ Part } & \multicolumn{6}{|c|}{$\%$ share of US imports } & \multirow{2}{*}{\multicolumn{2}{|c|}{$\begin{array}{l}\text { Total US imports } \\
\text { (in US\$ million) }\end{array}$}} \\
\hline & \multicolumn{2}{|c|}{ China } & \multicolumn{2}{|c|}{ Canada } & \multicolumn{2}{|c|}{ Mexico } & & \\
\hline & $\begin{array}{l}1995 \\
(\%)\end{array}$ & $\begin{array}{r}2005 \\
(\% 0\end{array}$ & $\begin{array}{c}1995 \\
(\%)\end{array}$ & $\begin{array}{c}2005 \\
(\%)\end{array}$ & $\begin{array}{c}1995 \\
(\%)\end{array}$ & $\begin{array}{c}2005 \\
(\%)\end{array}$ & 1995 & 2005 \\
\hline $\begin{array}{l}\text { Radio-broadcast } \\
\text { receivers for motor } \\
\text { vehicles }\end{array}$ & 6.7 & 17.0 & 0.1 & 0.3 & 19.7 & 49.6 & 2,074 & 2,577 \\
\hline $\begin{array}{l}\text { Instrument panel and } \\
\text { clocks for motor } \\
\text { vehicles }\end{array}$ & 0.3 & 16.9 & 66.9 & 4.9 & 0.8 & 8.1 & 16 & 14 \\
\hline $\begin{array}{l}\text { Brakes and servo- } \\
\text { brakes and parts }\end{array}$ & 2.1 & 12.1 & 39.7 & 24.7 & 12.5 & 21.3 & 2,034 & 4,010 \\
\hline $\begin{array}{l}\text { Non-driving axles } \\
\text { and parts }\end{array}$ & 0.2 & 8.9 & 37.7 & 5.5 & 9.7 & 27.0 & 388 & 632 \\
\hline $\begin{array}{l}\text { Parts for electrical } \\
\text { ignition or starting } \\
\text { equipment }\end{array}$ & 0.4 & 8.5 & 8.5 & 6.8 & 5.6 & 11.5 & 259 & 459 \\
\hline $\begin{array}{l}\text { Other parts and } \\
\text { accessories }\end{array}$ & 1.3 & 7.6 & 39.4 & 26.7 & 8.9 & 17.6 & 9,805 & 23,262 \\
\hline $\begin{array}{l}\text { Seats for motor } \\
\text { vehicles }\end{array}$ & 0.1 & 6.1 & 87.7 & 49.3 & 2.3 & 21.1 & 239 & 130 \\
\hline $\begin{array}{l}\text { Electrical lighting or } \\
\text { signalling, etc. }\end{array}$ & 1.3 & 4.8 & 18.5 & 9.8 & 9.0 & 51.6 & 359 & 1,233 \\
\hline $\begin{array}{l}\text { Electrical ignition or } \\
\text { starting equipment }\end{array}$ & 0.7 & 4.7 & 3.0 & 3.0 & 9.4 & 31.3 & 713 & 2,009 \\
\hline $\begin{array}{l}\text { Other parts and } \\
\text { accessories of bodies } \\
\text { (including cabs) }\end{array}$ & 0.2 & 2.6 & 29.9 & 38.6 & 22.7 & 37.8 & 4,107 & 9,307 \\
\hline $\begin{array}{l}\text { Parts for electrical } \\
\text { lighting or signalling }\end{array}$ & 0.2 & 2.4 & 16.5 & 3.8 & 27.0 & 54.5 & 312 & 803 \\
\hline $\begin{array}{l}\text { Drive-axles with } \\
\text { differential }\end{array}$ & 0.0 & 2.4 & 36.2 & 2.7 & 3.3 & 23.1 & 519 & 633 \\
\hline $\begin{array}{l}\text { Bumpers and parts } \\
\text { thereof }\end{array}$ & 0.6 & 2.4 & 65.4 & 55.1 & 2.1 & 7.8 & 491 & 849 \\
\hline
\end{tabular}


Table 6 China, Canada, and Mexico's share of US imports in 1995 and 2005, by part, ranked by China's share in 2005 (see online version for colours) (continued)

\begin{tabular}{|c|c|c|c|c|c|c|c|c|}
\hline \multirow[b]{3}{*}{ Part } & \multicolumn{6}{|c|}{$\%$ share of US imports } & \multirow{2}{*}{\multicolumn{2}{|c|}{$\begin{array}{l}\text { Total US imports } \\
\text { (in US\$ million) }\end{array}$}} \\
\hline & \multicolumn{2}{|c|}{ China } & \multicolumn{2}{|c|}{ Canada } & \multicolumn{2}{|c|}{ Mexico } & & \\
\hline & $\begin{array}{l}1995 \\
(\%)\end{array}$ & $\begin{array}{l}2005 \\
(\% 00\end{array}$ & $\begin{array}{l}1995 \\
(\%)\end{array}$ & $\begin{array}{c}2005 \\
(\%)\end{array}$ & $\begin{array}{l}1995 \\
(\%)\end{array}$ & $\begin{array}{c}2005 \\
(\%)\end{array}$ & 1995 & 2005 \\
\hline Ignition wiring sets & 0.0 & 2.0 & 2.2 & 1.4 & 79.0 & 84.8 & 2,498 & 5,887 \\
\hline $\begin{array}{l}\text { Rear-view mirrors for } \\
\text { vehicles }\end{array}$ & 0.2 & 1.7 & 3.0 & 2.2 & 7.0 & 30.8 & 72 & 162 \\
\hline $\begin{array}{l}\text { Other mountings, } \\
\text { fittings and articles } \\
\text { suitable for motor } \\
\text { vehicles }\end{array}$ & 0.5 & 0.6 & 44.6 & 60.7 & 3.5 & 16.6 & 275 & 755 \\
\hline Gearboxes & 0.0 & 0.3 & 1.4 & 16.4 & 0.3 & 5.1 & 3,835 & 5,972 \\
\hline $\begin{array}{l}\text { Bodies (including } \\
\text { cabs), for motor } \\
\text { vehicles }\end{array}$ & 0.0 & 0.0 & 62.7 & 47.4 & 21.2 & 1.2 & 215 & 823 \\
\hline $\begin{array}{l}\text { Internal combustion } \\
\text { piston engines for } \\
\text { propelling vehicles }\end{array}$ & 0.0 & 0.0 & 15.2 & 32.3 & 25.2 & 22.4 & 6,584 & 8,939 \\
\hline Total auto parts & 1.0 & 5.0 & $23.9 \%$ & $24.0 \%$ & $18.5 \%$ & $28.3 \%$ & 34,795 & 68,456 \\
\hline
\end{tabular}

\section{Canadian automotive firms: location, size and specialisation}

There are no Canadian lead firms (Canadian-owned auto assemblers) in the automotive industry, but the assembly sector continues to be the location for major new investment. A number of important new investments have recently been announced for Ontario. Toyota's new Woodstock assembly plant and Honda's engine plant in Alliston will result in the direct creation of at least 2500 jobs by 2009 . The number of jobs created indirectly, by parts suppliers that co-locate, will be a multiple of that number, though the correct multiplier is a topic of considerable debate. Equally important are the re-investments announced by Ford (a flexible assembly plant in Oakville), GM (its Beacon project) and DaimlerChrysler (C\$768 million worth of investments in its Brampton and Windsor facilities were announced in November 2005). ${ }^{13}$

Among the many advantages of producing cars in Ontario, several are listed most frequently. First, the Canadian plants have high labour productivity. Van Biesebroeck (2007) shows that Canadian plants take between 1.3 and 1.7 fewer hours to assemble a car than US plants do, after controlling for a host of other factors explaining productivity differences. The difference with Mexico averages almost 11 hours. Similar comparisons by J.D. Power and Charles River Associates (2001) also point to productivity advantages in Canadian plants. 
Second, the government-funded Canadian healthcare system substantially reduces the benefit costs for Canadian producers compared with US plants. The Canadian Automotive Partnership Council (CAPC) has estimated the costs of indirect benefits at $20 \%$ of payroll in Canada vs. $29 \%$ in the USA. ${ }^{14}$ Third, combined investment subsidies offered by the Federal and Provincial (Ontario) governments totalled US\$ 1 billion in 2004. Additional funds have been earmarked for transportation bottlenecks, in particular the border crossings with the USA. ${ }^{15}$ The Conference Board of Canada (2006) highlights the importance of investments in the border infrastructure.

The Canadian automotive parts industry consists of a varied group of firms and plants. Statistics on the Industry Canada website indicate that in 2005, 914 establishments were active in the sector, producing original equipment and aftermarket auto parts, components and systems. ${ }^{16}$ Total employment in 2005 was 97,282 and sales totalled C $\$ 30.9$ billion. This section will recap the three main trends in the industry and three characteristics of the Canadian suppliers will be examined: location, size distribution and specialisation.

\subsection{Three trends}

The three trends that have shaped the automotive industry over the last three decades can also be seen in the evolution of the Canadian supplier industry. These are: (1) the increased importance of parts suppliers' relative to final assembly; (2) the regional integration of the industry; and (3) the increased importance of imports from and production in low-wage Asian countries.

The aggregated information in the Canadian and US census of manufacturers is a major source of data. The information for the automotive sector is compiled each year in the DesRosiers Automotive Yearbook and complete statistics can also be obtained from Statistics Canada or the US Bureau of the Census. Information on production, value-added, employment, salaries, material and fuel costs, and the number of active enterprises is available and broken down to 5-digit North American Industry Classification System (NAICS) industries.

One way to identify the increasing importance of the parts sector relative to final assembly is to consider total employment in the two sectors. The trend for Canada mirrors to a large extent the pattern for the USA. Employment in the parts sector has increased markedly in both the USA and Canada; assembly employment is at best flat and even shows a slight decline in both the countries, although the decline happened later in Canada than in the USA. ${ }^{17}$

The third trend - increased imports from or production in low-wage (Asian) countries - is evident from a recent survey by the Canadian Auto Parts Manufacturers (APMA). The results were published in 2005 by the Asia Pacific Foundation of Canada under the title, The East Asian Automobile Industry: Opportunity or Threat? The main conclusion was that the opening to the East provided both opportunities and threats, but that Canadian firms perceived a lot of pressure from their clients to compete harder domestically and/or to establish manufacturing facilities overseas.

A number of facts illustrate the changing geographical activities of Canadian supplier firms. Table 7 displays the surveyed firms' answers to five questions about production activities, sourcing, investments and customer demands (firms answered the questions for the year 2004). 
Table 7 Changing geographical exposure for Canadian suppliers (see online version for colours)

\begin{tabular}{|l|c|c|c|c|c|}
\hline $\begin{array}{l}\text { Share of your firm's production } \\
\text { taking place in facilities located in }\end{array}$ & $69 \%$ & $17 \%$ & $12 \%$ & $1 \%$ & $0.3 \%$ \\
\hline $\begin{array}{l}\text { Share of supply needs that were } \\
\text { sourced from }\end{array}$ & $51 \%$ & $33 \%$ & $9 \%$ & $2 \%$ & $5 \%$ \\
\hline $\begin{array}{l}\text { Share of greenfield investments } \\
\text { (past five years) made in }\end{array}$ & $49 \%$ & $18 \%$ & $4 \%$ & $1 \%$ & $28 \%$ \\
\hline $\begin{array}{l}\text { 'In the last three years, has one or more of your major customers ever threatened to } \\
\text { switch to overseas suppliers?' }\end{array}$ & $71 \%$ Yes \\
\hline $\begin{array}{l}\text { 'In the last three years, has one or more of your major customers asked your firm to } \\
\text { initiate or expand activities in new geographical markets in order to facilitate its } \\
\text { own expansion agenda?' }\end{array}$ & $64 \%$ Yes \\
\hline $\begin{array}{l}\text { Countries mentioned most frequently: } \\
\text { USA (33\%), Republic of Korea (33\%), China (33\%), Mexico (22\%) }\end{array}$ \\
\hline
\end{tabular}

Source: Asia Pacific Foundation of Canada (2005)

Comparing the geographical distribution of three activities - production, sourcing and investment - a clear trend appears away from Canada and towards Asia. While almost $70 \%$ of the firms' production took place in Canada (in 2004), only $51 \%$ of their supplies were sourced domestically and only $49 \%$ of greenfield investments occurred in Canada. In contrast, Asia was the production location for only $0.3 \%$ of current output, but the source of $4.7 \%$ of inputs. Most importantly for the future, $28 \%$ of all greenfield investments by Canadian automotive parts suppliers were made in Asia, more than in the USA.

An important reason why Canadian firms invest overseas is explicit requests from current customers: $64 \%$ of firms reported that in the last three years they had received such a request to aid overseas expansion by their customers. Some suppliers also indicated that they believed serving Japanese-owned firms in other countries would increase their chances of gaining some of the supply business for the Canadian-based assembly plants of those same firms.

Competition from Asia has also made the domestic Canadian market more competitive. To the question whether any of their major customers has threatened (in the last three years) to switch to overseas suppliers, $71 \%$ of the surveyed firms answered in the affirmative. This competition is in addition to the greater competition from Mexico, now that Mexican firms have duty-free access to the Canadian market, and more importantly, the Mexican supplier industry has expanded and matured considerably.

\subsection{Locational patterns in the Canadian automotive supply base}

To illustrate the geographical location of the Canadian suppliers, the number of enterprises and distribution of exports is shown by province in Table 8. Statistics are limited to the automotive parts industry, including plastics and tyres. Of the 1764 firms in the Business Registry, 1007 or $57.1 \%$ of the total are in Ontario, followed by 350 $(19.8 \%)$ in Quebec, 144 (8.2\%) in British Columbia, and 108 (6.1\%) in Alberta. The sector as a whole is very export oriented, selling more than C\$21 billion worth of goods abroad in 2006. Exports are even more concentrated by province than the firm 
distribution. Ontario is responsible for $87.3 \%$ of Canadian automotive parts exports. As is well-known, the propensity to export is positively related to firm size. Ontario in particular has a large number of firms that employ more than 100 workers: $25.4 \%$ of all its parts suppliers. Even more striking, $78.7 \%$ of all the large parts suppliers in Canada can be found in Ontario. The concentration of larger firms in provinces with many firms means that the provincial concentration of total parts production is even more concentrated than the breakdown based on the number of firms would suggest.

Table 8 Provincial distribution of Canadian suppliers

\begin{tabular}{lccccc}
\hline & \multicolumn{3}{c}{ Enterprises } & \multicolumn{2}{c}{ Exports (2006) } \\
\cline { 2 - 6 } & Number & $\begin{array}{c}\text { Share of Canadian } \\
\text { total (\%) }\end{array}$ & $\begin{array}{c}\text { Fraction 100 } \\
+ \text { employees (\%) }\end{array}$ & $\begin{array}{c}\text { Current C\$ } \\
\text { (million) }\end{array}$ & $\begin{array}{c}\text { Share of Canadian } \\
\text { total (\%) }\end{array}$ \\
\hline Ontario & 1,007 & 57.1 & 25.4 & 19,126 & 87.3 \\
Quebec & 350 & 19.8 & 6.7 & 1,369 & 6.2 \\
Nova Scotia & 20 & 1.1 & 17.6 & 846 & 3.9 \\
British Columbia & 144 & 8.2 & 4.9 & 286 & 1.3 \\
Manitoba & 53 & 3.0 & 11.4 & 164 & 0.7 \\
Alberta & 108 & 6.1 & 6.7 & 101 & 0.5 \\
Saskatchewan & 35 & 2.0 & 9.4 & 18 & 0.1 \\
New Brunswick & 30 & 1.7 & 0.0 & 7 & 0.0 \\
PEI & 3 & 0.2 & 0.0 & 0.9 & 0.0 \\
NL \& L & 14 & 0.8 & 0.0 & 0.7 & 0.0 \\
Canada & 1,764 & 100.0 & 16.0 & 21,918 & 100.0 \\
\hline
\end{tabular}

Sources: Information on the number of enterprises comes from the Business Registry database and refers to NAICS industries 3363 'Motor Vehicle Parts Manufacturing', 316,293 Motor Vehicle Plastic Parts Manufacturing and 326,210 'Tire Manufacturing'. Export information is from the Industry Canada website and refers to the same industries: http://strategis.ic.gc.ca/sc_mrkti/tdst/ engdoc/tr_homep.html

More detailed information on the provincial breakdown of employment is found in the data compiled by the Institute for Competitiveness and Prosperity. ${ }^{18}$ Those statistics underscore the importance of Ontario, which employs 125,298 of the total 165,737 workers in the industry. ${ }^{19}$ Approximately 75,000 of these workers are in the parts sector.

Overall, $1.35 \%$ of the Canadian workforce works in the production side of the automotive industry and this rises to $2.5 \%$ for Ontario. Eight of the 15 most important automotive clusters are in Ontario and in certain areas account for an important share of the region's employment. In the Windsor area, which is dominated by parts producers, and in the Oshawa area, the Canadian home of GM, more than $10 \%$ of the workforce is employed directly by the automotive industry.

In the recent past, locations of US supplier plants were particularly concentrated (Klier and Rubenstein, 2006). In 1980, firms were concentrated in the Detroit area, on the east coast of Lake Huron in Michigan and around Chicago. ${ }^{20}$ There was also a large presence of supplier plants in Indiana and Ohio. At the same time in Ontario, plants clustered near the US border in Windsor and St. Catharines, around assembly plants in Southern Ontario, but the Greater Toronto metropolitan area also attracted a lot of industrial activity. 
Over the last 24 years, the geographic concentration has diminished in the USA as plant entry between 1980 and 2003 was particularly important in southern states. While Kentucky and Tennessee already had a solid supplier base before 1980, the establishment of several new assembly plants attracted many more new supplier plants. Moreover, entry was also important in northern Alabama and Georgia and in the western parts of the Carolinas and Virginia. In these states, the number of suppliers almost doubled, which increased their importance relative to the Midwestern states. Before 1980, 69\% of all new plant openings were in the Midwest, compared with 59\% post-1980. In contrast, the share of plants entering the southern USA jumped from $19 \%$ to $34 \%$ over the same period. Entry in the USA after 1980 was dominated by foreign plants, particularly in the south.

The Canadian experience differs from the USA in a number of respects. New entrants have tended to settle in the same locations as existing plants. The only established automotive area that seems to have attracted few new investments is the area east of Toronto, close to the GM plants in Oshawa, but farthest from the US market. Moreover, new North American suppliers are at least as common as foreign firms. This is especially surprising as the importance of Japanese assembly plants in Ontario (including the CAMI Joint Venture (JV)) increased greatly between 1980 and 2003.

\subsection{Problem areas for the Canadian supply base}

Trade infrastructure, especially border crossings, certainly influences firms' location decisions. The information in Table 9 is taken from the work of the CAPC, the main forum for government-industry consultation on issues of importance to the automotive industry. Its members meet annually to discuss progress towards objectives, launch new initiatives and report the status of specific topics, ranking them as 'immediate action required (red)', 'attention required (yellow)' or 'addressed (green)'.

At the top of the industry's agenda are trade infrastructure issues, especially emergency and security plans and border crossings. International trade issues are also a source of concern, especially the appreciation of the Canadian dollar and the Free Trade Agreement (FTA) between Canada and the Republic of Korea currently being negotiated. Issues of sustainability and regulatory harmonisation, which are receiving increasing policy attention, are also seen as areas where action is required. In contrast, issues that were priorities in the past two decades, such as adjusting fiscal policies and investment subsidies and especially human resource development, are no longer seen as requiring action. However, the concerns of this group are more representative of the opinions of the large firms in the industry, dominated by the OEMs and Magna. The APMA survey mentioned earlier showed that smaller firms find investment subsidies the most important government policy - with border infrastructure also mentioned prominently (see Van Biesebroeck, 2006).

A detailed study of the cluster of tool, die and mould makers in Windsor-Essex county, by Fitzgibbon et al. (2004), focuses on innovation. The researchers estimate that there are approximately 250 establishments engaged in tool and die, fixture and industrial mould-making, the vast majority of which are linked to the automotive industry. They interviewed a large number of participants in the industry, focusing in particular on the modes of innovation. An important observation is that only $2 \%$ of Canadian auto parts firms have a strategy based on proprietary product technology, and overall research and development expenditures in the auto sector are less than half of the Canadian 
manufacturing average. The lack of automotive R\&D activity in Canada is in part a legacy of the integration of the Canadian and US industries in the post-Auto Pact period when the Big 3 automakers centralised R\&D and design to the USA.

Table 9 Priority areas indicated by the CAPC (figures indicate urgency of required action on a $0-10$ scale)

\begin{tabular}{|c|c|c|c|}
\hline Working group & Main issues & October 2006 status & Overall \\
\hline \multirow{3}{*}{$\begin{array}{l}\text { Trade } \\
\text { infrastructure }\end{array}$} & Border & 7.5 & \multirow{3}{*}{8.0} \\
\hline & Emergency and security issues & 10.0 & \\
\hline & Rail/alternative vessels & 5.0 & \\
\hline \multirow[t]{5}{*}{ Sustainability } & Vehicle emissions and fuel standards & 6.3 & \multirow{5}{*}{7.2} \\
\hline & Feebates (fees or rebates) & 5.0 & \\
\hline & Energy & 10.0 & \\
\hline & Consumer programme & 8.8 & \\
\hline & World leader in manufacturing & 5.0 & \\
\hline \multirow[t]{5}{*}{ International trade } & Canadian dollar & 10.0 & \multirow{5}{*}{7.0} \\
\hline & FTA with the Republic of Korea & 10.0 & \\
\hline & Strategic trade/investment & 5.0 & \\
\hline & WTO round & 5.0 & \\
\hline & Trade with emerging economies & 5.0 & \\
\hline \multirow{4}{*}{$\begin{array}{l}\text { Regulatory } \\
\text { harmonisation }\end{array}$} & Formal policy & 5.0 & \multirow{4}{*}{6.3} \\
\hline & Fuel efficiency and emissions & 5.0 & \\
\hline & Recognition of self-certification & 10.0 & \\
\hline & Specific regulations & 6.7 & \\
\hline \multirow[t]{4}{*}{ Innovation } & Financial support & 4.5 & \multirow{4}{*}{5.5} \\
\hline & Consumer support & 8.8 & \\
\hline & Private-Public capacity & 5.0 & \\
\hline & Light materials - SME & 5.0 & \\
\hline \multirow{3}{*}{$\begin{array}{l}\text { Fiscal and } \\
\text { investment }\end{array}$} & Investment subsidies & 2.5 & \multirow{3}{*}{4.7} \\
\hline & Taxation & 5.5 & \\
\hline & Lessor liability & 2.5 & \\
\hline \multirow{3}{*}{$\begin{array}{l}\text { Human resources } \\
\text { development }\end{array}$} & Analysis and strategy & 0.0 & \multirow{3}{*}{1.4} \\
\hline & Training initiatives & 1.7 & \\
\hline & Cooperative and LT projects & 2.5 & \\
\hline
\end{tabular}

Note: The overall status is calculated by taking a simple average over all topics listed using 0 (green), 5 (yellow), 10 (red), which yields a score from 0 to 10 with higher numbers indicating greater need for immediate action.

Source: CAPC website at http://www.capcinfo.ca

The interviews conducted by Fitzgibbon and co-authors support the view that there is not a strong knowledge-based innovation strategy among Canadian auto parts producers in general although there is strong evidence of a focus on incremental process innovation. While the University of Windsor has established several research centres to foster collaborative $\mathrm{R} \& \mathrm{D}$ with the automotive industry, it has by and large focused on the OEMs and only a few of the largest suppliers. 


\subsection{Specialisation in the Canadian automotive supply base}

Information from the census of manufacturers allows analysis of the specialisation of the Canadian parts industry. For Canada, the parts industry is broken down into eight 5-digit sectors; the US data have been aggregated to cover the same categories. Employment is used in Figure 4 to show which sectors Canadian firms are specialising in relative to the USA.

Figure 4 Breakdown of the automotive parts sector by employment shares, 2003

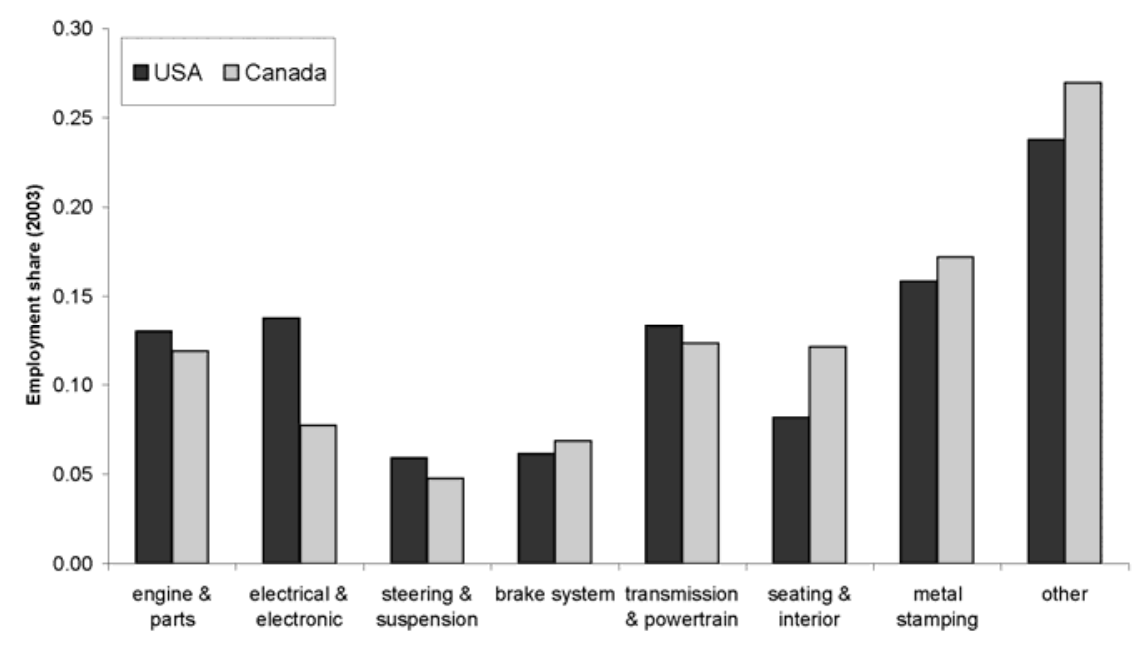

Source: Authors' calculations based on information from Statistics Canada and US Bureau of the Census

The largest Canadian sub-sector is 'other automotive parts' where $27.0 \%$ of Canadian parts workers are employed, compared with $23.8 \%$ in the USA. The second largest sector in Canada is 'metal stampings', employing a further $17.2 \%$ of workers. In the USA, the 'metal stampings' sector is also the second largest employer but in terms of value-added, three other sectors are more important. In order, these are 'power trains and transmissions', 'engines and engine parts' and 'electrical and electronic parts'. These are the three highest value-added per worker sectors of the parts industry and their combined employment share in the USA is substantially higher than in Canada. The difference is largest for the electrical and electronic parts sector, which has the highest value-added per worker in the industry, but is also expanding the most rapidly. The sector where the Canadian employment share is most above the USA is 'seating and interiors', one of the strongest areas of Magna International. This is the value chain segment with the lowest value-added per worker.

The specialisation of the Canadian parts sector can be looked at in a different way. In Figure 5, a number of relative measures are plotted, each indicating the position of the Canadian industry relative to its US counterpart. The first series (in yellow) indicates the relative employment share of the Canadian sector. For the parts sector as a whole, Canada accounts for $11.7 \%$ of the combined USA and Canadian employment. This share is slightly lower in 'engines and engine parts' $(10.8 \%)$ and slightly higher in the 'brake system' sector (12.9\%). Normalised by $11.7 \%$, this gives the values of 0.92 and 1.10 , respectively, which are displayed in the figure. 
Figure 5 Relative specialisation and productivity performance of Canadian parts sectors

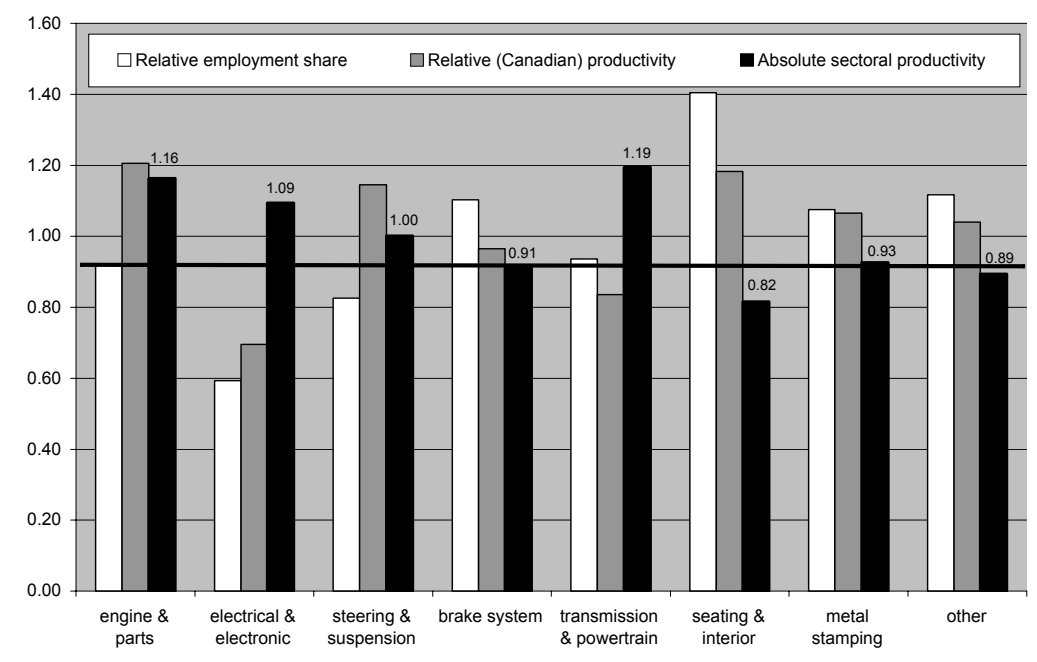

Source: Authors' calculations based on information from Statistics Canada and US Bureau of the Census

The red bars compare labour productivity in Canada and the USA, normalised by the relative Canadian productivity in the total parts sector. On an average, a Canadian employee in the parts sector generated value-added of $\mathrm{C} \$ 121,000$ in 2003 , which was $31 \%$ below the value-added per worker in the US industry - C $\$ 176,000$ - in the same year. Canadian labour productivity clearly varies across sectors, but it is always lower than in the USA. The best (relative) Canadian performance is in 'engines and engine parts', where the 1.20 figure on the graph indicates that the gap with the US labour productivity is only $17 \%$, i.e. $20 \%$ better than the average gap $(1.20 \times 0.69=0.83)$.

In most cases the relative employment and value-added shares are related to the labour productivity numbers. For example, in the 'electrical and electronic parts' sub-sector, the share of Canadian employment in the North American total is much below the average for the parts sector, and its productivity level is also more than $30 \%$ below the average. Similarly, in 'seating and interiors', Canada has a disproportionate share, but also a relatively high labour productivity.

The white bars indicate in an absolute sense how labour productivity compares across the different sub-sectors (taking an employment-weighted average of Canada and the USA). For example, 'steering and suspension' had a value-added per employee of $\mathrm{C} \$ 171,709$, almost identical to the average for the entire parts sector across the two countries, which was C $\$ 171,462$. Clearly, the two sectors that Canada is specialising in the least - its share is low and its productivity gap with the USA is highest - are two of the highest value-added per worker sub-sectors: 'electrical and electronic parts' and 'power trains and transmissions'. The only high value-added industry that Canada is well-represented in is 'engines and engine parts', but here value-added per worker has plunged from $\mathrm{C} \$ 224,000$ in 1997 to $\mathrm{C} \$ 168,000$ in 2003, while value-added per worker has risen by $50 \%$ in the USA over the same period, partly reflecting capacity utilisation. Quite starkly, the four sectors where the Canadian employment share exceeds the part sector average ('brakes', 'seating', 'stamping' and 'other') are the four sectors with the lowest value-added per worker. 


\section{Canada's position in the automotive global value chain}

Even though there are no Canadian lead firms, i.e. all Canadian-owned firms in the automotive industry are suppliers, there are fewer large Canadian suppliers than one would expect based on the large assembly sector in Canada. Figures in the first column of Table 10 show that the share of Canadian firms among the top 150 largest parts suppliers to the automotive industry ${ }^{21}$ peaked at $6.7 \%$ in $1999-2000$, after which the number on the list fell to $4 \%$, or six firms, in 2005 . The Canadian firms' share of sales started a little higher and rose steadily, thanks to the impressive growth - both organic and by acquisition - of Magna International. ${ }^{22}$ The corresponding figures for the worldwide supplier list, which are only available from 1999 onwards, are in columns 4 and 5 and follow a similar pattern. Only two firms, Magna and Linamar, remained on the list in 2005 , but their share of sales is larger and has increased steadily over time.

As a benchmark, the share of vehicle production in North America and worldwide that takes place in Canadian assembly plants has been recorded in the third and sixth columns. In North America, the fraction of vehicles produced in Canada was five times higher than the share of sales by top Canadian firms in 1992, but only twice as high in 2005. In contrast, the worldwide sales of Canadian suppliers in 2005 exceeded the Canadian share in worldwide vehicle production $-4.8 \%$ vs. $4.1 \%$. In sum, Canadian suppliers are underrepresented in the North American industry, but this is not the case on the world stage, thanks to the presence of a few very successful multinationals.

Table 10 Canadian presence on the list of the world's largest automotive parts suppliers

\begin{tabular}{|c|c|c|c|c|c|c|}
\hline & \multicolumn{3}{|c|}{ North America } & \multicolumn{3}{|c|}{ Worldwide } \\
\hline & $\begin{array}{l}\text { Fraction of } \\
\text { firms (\%) } \\
\text { (on list) }\end{array}$ & $\begin{array}{l}\text { Fraction of } \\
\text { sales (\%) } \\
\text { (on list) }\end{array}$ & $\begin{array}{c}\text { Fraction of } \\
\text { vehicle } \\
\text { production (\%) }\end{array}$ & $\begin{array}{l}\text { Fraction of } \\
\text { firms (\%) } \\
\text { (on list) }\end{array}$ & $\begin{array}{l}\text { Fraction of } \\
\text { sales (\%) } \\
\text { (on list) }\end{array}$ & $\begin{array}{c}\text { Fraction of } \\
\text { vehicle } \\
\text { production (\%) }\end{array}$ \\
\hline 1992 & 3.0 & 3.1 & 15.4 & & & \\
\hline 1993 & 3.0 & 3.6 & 15.8 & & & \\
\hline 1994 & 5.0 & 3.2 & 14.8 & & & \\
\hline 1995 & 5.3 & 3.3 & 15.7 & & & \\
\hline 1996 & 5.3 & 4.0 & 15.5 & & & \\
\hline 1997 & 4.7 & 4.0 & 16.0 & & & \\
\hline 1998 & 6.0 & 4.5 & 16.0 & & & \\
\hline 1999 & 6.7 & 5.2 & 17.4 & 4 & 3.3 & 5.5 \\
\hline 2000 & 6.7 & 5.8 & 16.8 & 3 & 3.3 & 5.2 \\
\hline 2001 & 5.3 & 5.9 & 16.0 & 4 & 3.8 & 4.5 \\
\hline 2002 & 4.7 & 5.8 & 15.7 & 3 & 3.8 & 4.5 \\
\hline 2003 & 5.3 & 6.6 & 16.2 & 2 & 4.1 & 4.4 \\
\hline 2004 & 5.3 & 6.8 & 16.7 & 3 & 4.7 & 4.2 \\
\hline 2005 & 4.0 & 7.9 & 15.4 & 2 & 4.8 & 4.1 \\
\hline
\end{tabular}

Source: Authors' calculations based on information from the Automotive News top supplier lists (various years) and Ward's Automotive Yearbook (production statistics) 
The initial wave of mergers among component suppliers in the 1990s propelled several Canadian firms into the top 150, but the continuation of the mergers led to several foreign takeovers. Another way 'Canadian' firms have left the list is by the closing or relocation of regional headquarters. Some foreign-owned firms with important Canadian operations have folded their Canadian headquarters into their parent headquarters. While these firms were never really Canadian, their regional headquarters often had design or engineering centres that provided a more stable and permanent range of activities to complement manufacturing. Sturgeon et al. (2007) provide a comprehensive overview of the experiences of all Canadian firms that ever made to the top 150 list.

\section{Conclusions and recommendations}

Key findings of this study can be summarised as follows:

- the automotive industry in Ontario is still a strong industrial centre, but the supporting supply base within and outside Canada is shifting in composition and location

- the shift of the industry to the south within North America is real but gradual and mostly within the USA

- $\quad$ lead firms bring primary and secondary investment with them

- $\quad$ it is possible that Japanese lead firms will continue to invest in Canada, which is likely to trigger further investment by Japanese suppliers

- most design work is concentrated near lead firm headquarters; none of these are located in Canada

- Canadian firms are suppliers, not assemblers (lead firms). Most are small and not technologically advanced. Only Magna International, and to a lesser extent Linamar, have a truly global network, although many firms operate internationally

- $\quad$ parts imports from low-wage countries in Asia, especially China, are small but increasing rapidly

- parts exports from Mexico to the USA are increasing rapidly.

Although the Canadian automotive industry is not currently in crisis, it faces the possibility of gradual marginalisation within automotive global value chains over the long term. It is part of a global industry with strong regional elements nested within it. At the global level, the industry is shifting investment towards large developing countries, such as China, India and Brazil, where markets are growing rapidly (Humphrey and Memodovic, 2003). At the regional level, Canada's ties to the US market have been the lifeblood of the industry, so the continued viability of regional production, at a time when other industries are rapidly shifting production to China, might seem to be good news.

But a gradual and seemingly inexorable shift of production within North America, to southern USA (for final assembly and parts) and Mexico (for parts), and the eroding market share of the Big 3 American automakers, is slowly undermining Canada's position. Another threat to Canada, and the North American automotive supply base as a whole, comes from rising parts imports from outside North America, especially China. 
For Canada, all of these vulnerabilities stem from the importance of the automotive parts sector and the fact that Canadian firms are confined to the supplier role in automotive global value chains.

These conclusions suggest that Canadian policymakers need to focus on two main areas for maintaining and upgrading the position of the industry within automotive global value chains. The first is to enhance Canada's ability to attract new investment in final assembly, especially by automakers that are currently increasing their share of the North American market, such as Toyota and Honda. As their market share has increased, a larger share of US demand has been met through imports from Japan. These firms are responding to this growing imbalance by planning a new wave of assembly plant investment in North America. However, judging from recent investment patterns and company statements, the southern USA appears to be the primary target for this new investment. Since the automotive industry tends to operate in clusters, with suppliers often serving several nearby assembly plants, the urgent question for Canadian policymakers is how they can continue to attract a substantial share of this new investment.

The second policy area is support for upgrading the Canadian supply base. The dominant firms in the industry are all based in countries other than Canada, which is headquarters to only one of the top 100 suppliers to the automotive industry and only a handful of the top 150 North American suppliers. Domestic firms tend to be small and focused on low value-added segments. Labour productivity is extremely low in these small firms and they tend to specialise in the least technology-intensive areas of the industry, such as plastics, metal stampings and interior parts (the only parts segments where Canada has a positive balance of trade). Few Canadian suppliers, with the exception of a handful of the largest firms, have the capability to support their customers outside North America. Canadian parts suppliers, like automotive suppliers everywhere, need to improve their ability to work for multiple customers, both within and outside the automotive industry. This has become even more critical in an era when US assemblers are announcing new plant closures and employment cutbacks in North America virtually every month.

Being tied closely to the Big 3 presents problems, but market share in the automotive industry can be unpredictable, and being tied too closely to even the most successful firm can create problems for suppliers as conditions change. However, there are historical, structural and technical reasons why it is difficult for suppliers to develop profitable relationships with multiple customers in the automotive industry and it is beyond the reach of government policy to change these longstanding conditions. For example, extremely high barriers to entry mean that Canadian firms would be unable to develop new products and influence the trajectory of market development on their own terms. As a result, most innovative work in the industry will continue to take place outside Canada. It will be difficult for Canada to generate new economic development through innovation because firms tend to keep the industry's most innovative work closely tied to the main research and development facilities of lead firms.

Given the many ways in which central and provincial government policy in Canada already supports the automotive industry, either directly through incentives for new investments in final assembly, or indirectly through infrastructure improvements, skill development and R\&D credits for local firms, it is important to develop fresh thinking about how government policy can improve the position of Canada within automotive global value chains. It is fortunate that changes in the automotive industry tend to unfold 
relatively gradually. This gives Canadian policymakers a window of opportunity to help Canadian firms scale up to meet the new lead firm requirements for global investment and production, or, failing that, to diversify and gradually shift away from heavy dependence on the automotive industry.

The main recommendations of the study are:

- work to attract new assembly plant investment, especially by Japanese firms, which are gaining market share in North America and treat their suppliers better

- help domestic suppliers scale up and set up facilities outside Canada

- help suppliers serve multiple customers, including automotive and non-automotive customers

- reduce border bottlenecks to allow Canadian suppliers to serve US plants

- help suppliers develop export opportunities to take advantage of growing assembly operations in emerging economies and to diversify sales.

\section{References}

Asia Pacific Foundation of Canada (2005) The East Asian Automobile Industry: Opportunity or Threat?, Results of a survey of Canadian Auto Parts Manufacturers, Working Paper 2005-2, January.

Automotive News (annual) Top 150 North American Suppliers.

Charles River Associates (2001) Competitiveness Factors for Attracting and Maintaining Automotive Investment: Comparison between Canada and Mexico, Report prepared for Industry Canada and The Ontario Ministry of Economic Development.

Conference Board of Canada (2006) Canada's Auto and Auto Parts Industry: Canadian Industrial Outlook, Autumn.

DesRosiers Automotive Yearbook (annual) DesRosiers Automotive Consultants

Dicken, P. (2006) Global Shift: Reshaping the Global Economic Map in the 21st Century, 5th ed., Sage Publications, London.

Fitzgibbon, S., Holmes, J. and Rutherford, T. (2004) Innovation in the Automotive Parts Industry: A Case Study of the Windsor-Essex Region, Working Paper, Queens University.

Humphrey, J. and Memodovic, O. (2003) 'The global automotive industry value chain: what prospects for upgrading by developing countries?', Sectoral Studies Series, United Nations Industrial Development Organization, Vienna.

Klier, T. and Rubenstein, D. (2006, May) 'The US auto supplier industry in transition', Chicago Fed Letter, No. 226.

McAlinden, S.P. (2006, April 19) 'There's no place like home - the geography of automotive employment', Presentation to the Chicago Federal Reserve Conference on The New Geography of Auto Production, Detroit, MI.

Milgrom, P. and Roberts, J. (1997) Johnson Control: Georgetown, Kentucky, Case Study, Stanford University Graduate School of Business.

Sturgeon, T.J., Van Biesebroeck, J. and Gereffi, G. (2007) Prospects for Canada in the NAFTA Automotive Industry: A Global Value Chain Analysis, Industry Canada Report.

Van Biesebroeck, J. (2005, forthcoming) 'Trends and complementarities in the Canadian automobile industry', in Chen, Z. and Duhamel, M. (Eds): Industrial Economics and Performance in Canada, McGill University Press, Montreal.

Van Biesebroeck, J. (2007) 'Complementarities in automobile production', Journal of Applied Econometrics, Vol. 22, No. 7, pp.1315-1345. 
Van Biesebroeck, J. (2006) The Canadian Automotive Market, Report prepared for International Trade Canada. Available online at: http://www.dfait-maeci.gc.ca/tna-nac/documents/ JVB-en.pdf

Van Biesebroeck, J. (2007, March) 'The cost of flexibility', Assembly Automation, Vol. 27, No. 1, pp.55-64.

Ward's Automotive Yearbook (various years) Ward's Communications, Inc., Southfield, MI.

\section{Notes}

1 Automotive assembly plants in Canada are owned by CAMI, a JV between General Motors and Suzuki, DaimlerChrysler, Ford, GM, Honda and Toyota. All 12 active assembly plants are located in Southern Ontario and a new Toyota facility is slated to open in 2008 in Woodstock, Ontario.

2 Unless otherwise noted, all figures are in Canadian dollars.

3 Automotive industry data are drawn from The Statistical Survey of Canada's Automotive Industry, compiled annually by Industry Canada (sectoral trade and employment data are from Statistics Canada).

4 It is expected that the profit margins of the three US producers will recover somewhat in the following years (see Conference Board of Canada, 2006), but the market share losses are unlikely to be reversed in the short to medium term.

5 Figures are based in the authors North American OEM Database, compiled from Automotive News Magazine, Company websites and various news reports.

6 When the trends in the integration of the North American automotive industry are examined by the sources of vehicles supplied to the USA.

7 An exception was Nissan in Mexico, but production there was predominantly for the local Mexican market.

8 For a brief introduction to the modern organisation of the industry, contrasting the Japanese roots with the North American legacy, see Milgrom and Roberts (1997).

9 In 1992, the list was limited to the top 50 OEM suppliers for North America. It was expanded to the top 100 suppliers in 1993 . (The top 25 suppliers to the Mexican industry were listed separately.) In 1995, the current format was introduced.

10 The consumer price index for new vehicles saw a cumulative increase from 1992 to 2005 of $4.3 \%$; between 1997 and 2005, it recorded a decline of 5.5\%.

11 OEM suppliers is an industry terms referring to direct suppliers of 'original' parts sold to automakers as opposed to suppliers of aftermarket replacement parts sold to repair shops and the general public.

12 As firms often list a large number of products, we only switched the dummy on if at least half of the products listed in Automotive News were important Chinese imports.

13 The emergence of fully flexible plants that can produce a wide range of vehicles is likely to have important repercussions on the industry. Van Biesebroeck (2007) analyses the costs and benefits of flexibility.

14 These numbers are quoted in A Call for Action, A Canadian Auto Strategy, October 2004, which can be found on the CAPC website: http://www.capcinfo.ca

15 Details on funding packages can be found in Van Biesebroeck (2005).

16 This document is published annually by Industry Canada and can be consulted online at http://strategis.ic.gc.ca/epic/site/auto-auto.nsf/en/h_am01661e.html

17 One difficulty is the introduction of the NAICS industry code in both countries in 1994, replacing the Canadian and US Standard Industrial Code. As the earlier classification was slightly different for automotive parts in the two countries, the comparison should be done cautiously across the 1994 breakpoint. 
18 The data can be accessed at http://www.competeprosper.ca/clusters/

19 The definition of the automotive industry includes parts production and final assembly. The inclusion of the final assembly sector makes it more difficult to compare salary levels in Ontario with other provinces, due to the higher pay in final assembly plants.

20 The econometric evidence indicates that plants farther from Detroit tend to be bigger, as are plants owned by foreign firms or first-tier suppliers.

21 Firms are listed as Canadian if they are privately held Canadian firms or if they are listed on the Toronto Stock Exchange. Note that several Canadian firms are listed with a US address, often their North American sales centre, on the Automotive News list.

22 In 2005, the share of sales by the largest Canadian firm, Magna International, in the Canadian total was $79 \%$ (on the list of top North American suppliers) and $94 \%$ (on the more selective list of top suppliers worldwide). 